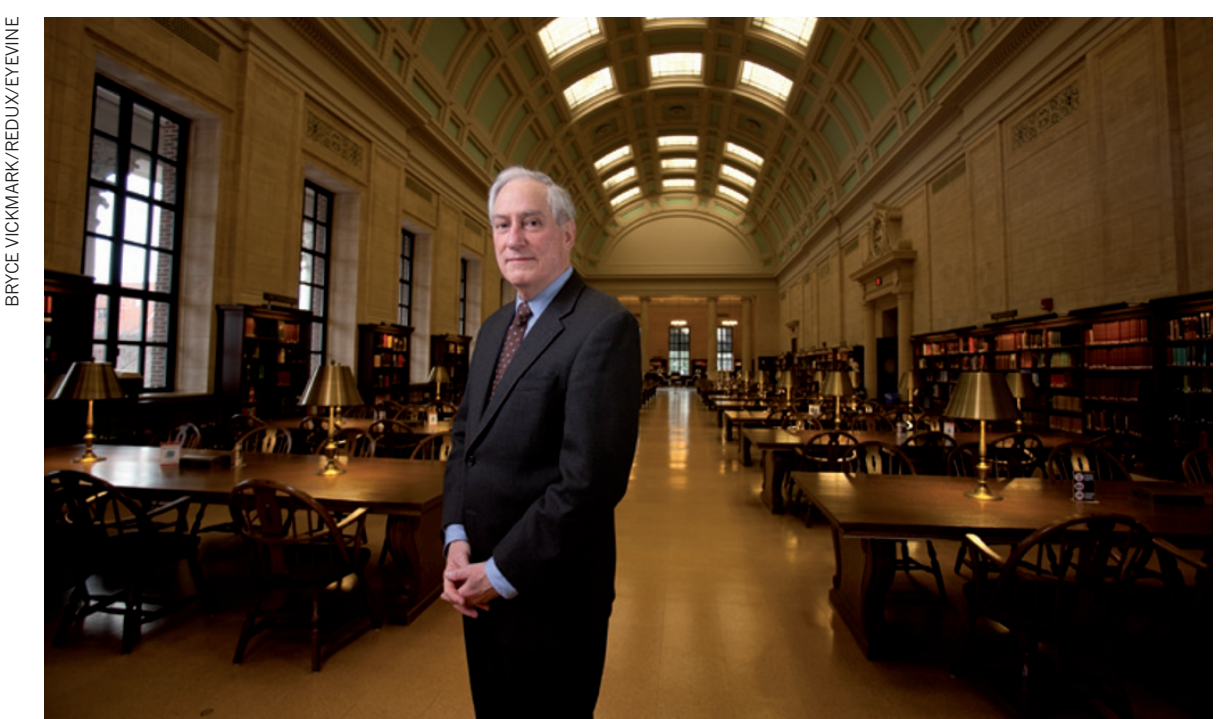

Q\&A Robert Darnton

\title{
Knowledge liberator
}

Robert Darnton heads the world's largest collection of academic publications, the Harvard University Library system. He is also a driver behind the new Digital Public Library of America. Ahead of its launch in April, he talks about Google, science journals and the open-access debate.

\section{How did you come to run the Harvard libraries?}

As a graduate student at Oxford in 1963, I began writing about books in revolutionary France, helping to found the discipline of book history. I was in my academic corner writing about Enlightenment ideals when the Internet exploded the world of academic communication in the 1990s. As president of the American Historical Association I started a programme to make dissertations into e-books in 1999. Before I knew it I was involved in other electronic projects. Harvard invited me to become director of the libraries in 2007. From that position I have been trying to help grow the digital landscape to serve the public good.

\section{Did you get involved in Google's effort to scan books?}

In 2002 Google began an ambitious project to digitize every book in the world. It was intended as a search project: type in a query, and Google would show you snippets. They asked university libraries for books, which they would scan for free. At Harvard we didn't permit them to take works under copyright, but other libraries gave them everything.

\section{What happened then?}

In 2005 Google was faced with a lawsuit from authors and publishers claiming copyright infringement. After three years of negotiations, they came back with a settlement for a commercial library. Digital Public Library Google would split of America launch the profits with Boston Public Library, copyright owners, Boston, Massachusetts. leaving libraries to 18-19 April 2013. buy back digital subscriptions to their own books. In 2011, a federal court declared the settlement unacceptable. Now Google has a great digital database of books, which it can use in cooperation with publishers to sell books, but in my view it's not creating the kind of library that was promised.

\section{So you're launching a public alternative?}

Along with research libraries, archives and museums throughout the country, Harvard is supporting the non-profit Digital Public Library of America (DPLA). At its launch in April, the DPLA will make freely available online large runs of documents from digitized special collections. Harvard will contribute, among many previously inaccessible documents, 243 rare medieval manuscripts and 3,628 daguerreotypes, including the first photographs of the Moon. This initial core of offerings will probably grow to include about 5 million books in the public domain and perhaps 2 million 'orphan' books whose owners cannot be found. We have also made

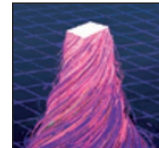

\section{THE FUTURE OF PUBLISHING A Nature special issue. nature.com/scipublishing}

our data compatible with Europeana, a digital library that gathers collections from 27 countries.

\section{Will the DPLA contain science?}

We do not currently have plans to digitize textbooks or journals. But sometimes the raw data are more important: scientists no longer leave a paper trail. Digital data are more fragile than printed material. Eventually we want our online library to preserve raw experimental data, not just published results.

\section{Why not science journals?}

In recent years their prices have risen four times faster than inflation. An average chemistry journal subscription is more than US $\$ 4,000$ annually. An institutional subscription to the Journal of Comparative Neurology costs more than $\$ 29,000$ per year. Libraries used to spend half their budget on journals; now many spend $90 \%$ and can't afford monographs.

\section{How did this situation arise?}

Academic publishing grew up in the nineteenth century, when professional associations needed to disseminate their members' works. Recently, publishers have taken over, creating thousands of journals so specialized that there is little competition. Most research is funded by taxes, but the taxpayers do not have free access to the results of the work that they financed. Academics do the research, write the papers and referee them - all for free - then buy back their work at exorbitant prices. Publishers can rake in the money, because libraries can't unsubscribe without alienating scientists. It wasn't a conspiracy or the result of wicked aims. But the whole system is fundamentally flawed and we must do something about it.

\section{What is Harvard doing to fix it?}

The Harvard faculty has decided that the price increases are unsustainable. We have 73 libraries and each must limit the haemorrhage of funds. In April 2012, a faculty council asked faculty and students to consider not contributing to journals that charge outrageous prices. But voluntary effort alone won't solve the problem. We've created a repository where all Harvard professors by default must deposit their articles, although they can opt out, and the traffic from around the world is astonishing. The university will pay most of the processing fees for articles submitted to open-access journals such as those of the Public Library of Science. By working with other universities, we hope to make most journals open-access and eventually to change the economics of journal publishing. Open-access journals get more hits than closed ones. This is where the future lies. 